Tintti Klapuri \& Jenniliisa Salminen

\title{
Kulttuurisen muistin tilat Ljudmila Ulitskajan romaanissa Vihreän teltan alla ja Jelena Tšižovan romaanissa Naisten aika
}

Pyrkimys historian toisinkirjoittamiseen tarjoamalla vaihtoehtoisia, aiemmin vaiennettuja narratiiveja on ollut sodanjälkeisen venäläisen kirjallisuuden keskeisiä suuntauksia. Vaihtoehtoiset historiantulkinnat näkyvät jo suojasään eli Stalinin kuolemaa seuranneen rajoitetun vapauden aikakauden kirjallisuudessa sekä myöhemmin 1970-luvulla, erityisesti Juri Trifonovin lähihistoriaa analysoivassa romaanissa Talo rantakadulla (Dom na naberežnoi, 1976), jossa tyypillinen neuvostoihminen esitetään ensisijaisesti porvarillisena omaisuuden tavoittelijana. 1980-luvun glasnostin mahdollistamassa historiabuumissa tilitetään edellisten vuosikymmenien traumaattisia kokemuksia niin muistelmissa, omaelämäkerrallisissa teoksissa kuin fiktiossakin, josta paras esimerkki on Anatoli Rybakovin romaani Arbatin lapset (Deti Arbata, 1987). Rankemmin lähihistoriaa tarkastellaan erityisesti naisten kirjoittamassa 90-luvun vaihteen naturalistisessa tšernuhassa eli "mustassa proosassa" kuten Ljudmila Petruševskajan tuotannossa, jossa huomio kiinnitetään neuvostoyhteiskunnassa vaiettuihin ilmiöihin: perheväkivaltaan, insestiin ja alkoholismiin.

2000-luvulla venäläisen kirjallisuuden painopiste on siirtynyt erilaisiin yhteiskuntakriittisen kirjallisuuden muotoihin. Yhtäältä kyse on dystooppisisista yhteiskuntakuvauksista, joissa uusi Venäjä usein vertautuu Neuvostoliiton kaltaiseen totalitarismiin, ja toisaalta niin kutsutusta uudesta realismista, jossa samoin kuvataan pääosin jälkisosialistista yhteiskuntaa. ${ }^{1}$ Kuitenkin myös neuvostoajan käsittely jatkuu edelleen. Kaksi keskeistä nykykirjailijaa, Ljudmila Ulitskaja ja Jelena Tšižova, on viimeaikaisissa teoksissaan palannut sodanjälkeisen historian kysymyksiin ja aivan erityisesti kulttuurisen muistin välittymisen problematiikkaan kylmän sodan aikakaudella. Artikkelissamme tarkastelemme Ulitskajan laajaa realistista sukupolviromaania Zeljonyi šatjor (2010, Vihreän teltan alla; tästä eteenpäin VTA) ja Tšižovan kerrontatekniikaltaan kokeellisempaa, ilmestymisvuotenaan Venäjän Bookerilla palkittua romaania Vremja žentštš̀in (2009, "Naisten aika”; tästä eteenpäin NA). ${ }^{2}$

Ljudmila Ulitskaja (s. 1943) on Venäjän nykykirjallisuuden näkyvimpiä hahmoja, joka ottaa julkisuudessa avoimesti ja kriittisesti kantaa yhteiskunnallisiin kysymyksiin. Hänen on usein nähty välittävän neuvostotodellisuutta nykylukijalle realistisesti, sellaisena kuin se erityisesti intelligentsijan perspektiivistä näyttäytyi. Niinpä esimerkiksi 
Vihreän teltan alla -romaania on arvosteltu siitä, että kaikki sen faktat eivät pidä paikkaansa (ks. Kunik 2013), mikä kertoo teosta todella luettavan eräänlaisena aikalaistodistuksena. Jelena Tšižova (s. 1957) puolestaan pohtii tuotannossaan menneisyyden merkitystä nykyisyydelle ja erityisesti naisten roolia kulttuurin välittäjinä. Hän on todennut, että yksi nyky-Venäjän suurimmista ongelmista on sen historiallisen muistin puutteellisuus, joka hänen mielestään juontuu sodassa traumatisoituneiden miesten kyvyttömyydestä siirtää kokemuksiaan eteenpäin. Naisten rooli historian ja kulttuurin kantajina on voimakkaasti läsnä myös romaanissa Naisten aika.

Ymmärrämme kulttuurisen muistin käsitteen Jan Assmannin (1995, 126-130; 2008, 109-110) tapaan yhteisön identiteettiä rakentavana ja sen muista yhteisöistä erottavana, sukupolvelta toiselle siirtyvänä tietona, joka ohjaa yhteisön toimintaa ja määrittyy uudelleen uudessa historiallisessa kontekstissa. Kulttuurisen muistin käsite eroaa toisesta keskeisestä yhteisöllisen muistin käsitteestä, kommunikatiivisesta muistista, jolla tarkoitetaan arkista muistitiedon välittymistä. Kommunikatiivinen muisti kattaa korkeintaan muutaman sukupolven, kun taas kulttuurinen muisti viittaa yhteisön laajempaan ja institutionalisoidumpaan kollektiiviseen identiteettiin: sen viittauskohdat menneisyydessä ovat kanonisoituja eivätkä muutu historian kuluessa, niitä vain sovelletaan vastaamaan kulloiseenkin yhteiskunnalliseen todellisuuteen.

Kulttuurista muistia rakennetaan sekä virallisten että epävirallisten käytänteiden kautta. Esimerkiksi Neuvostoliitossa voidaan nähdä kaksi erillistä, joskin toisistaan riippuvaista, kulttuurisen muistin rakentumisen tapaa, virallisen neuvostokulttuurin ja epävirallisen tai vaihtoehtoisen "toisen" kulttuurin kanavat, joita molempia määrittää pyrkimys yhteisön identiteetin vahvistamiseen kanonisoidun muistin avulla. Hyvä esimerkki tästä on se, miten sekä neuvostokirjallisuuden kaanon että 1960-luvulta lähtien korostunut vaihtoehtoinen kaanon molemmat tukeutuivat 1800-luvun klassiseen venäläiseen kirjallisuuteen. Virallisen kirjallisuuskaanonin rakentamisessa sitä luettiin sosialistisen realismin lävitse, kun taas epävirallisessa kaanonissa 1800-luvun klassikoita tarkasteltiin neuvostokriittisestä näkökulmasta, tietoisina uudesta läntisestä kirjallisuudesta ja vasten 1900-luvun alun modernistisia suuntauksia.

Esitämme, että Ulitskajan ja Tšižovan romaaneissa vaihtoehtoinen kulttuurinen tietoisuus yhdistyy kulttuurisin ja kirjallisuushistoriallisin merkityksin ladattuun tilaan. Ulitskajan romaanin keskiössä on moskovalainen älymystö ja Moskovan kaunokirjallinen maantiede, kun taas Tšižovan teoksen tematiikka heijastelee Pietarin-Leningradin kaupunkiin yhdistyvää kulttuurista mytologiaa. Läntisessä kaunokirjallisen kaupunkitilan tutkimuksessa tapahtunut, sosiologiasta ja kulttuurisesta maantieteestä ammentanut "tilallinen käänne" (spatial turn) ei ole näkynyt lainkaan yhtä voimakkaasti venäläisessä tutkimuksessa, jossa erityisesti Pietarin kaunokirjallisia representaatioita on perinteisesti tarkasteltu pääosin semioottisina merkitystiloina, "pietarilaistekstinä". ${ }^{3}$ Vaikka sekä 
Ulitskajan että Tšižovan romaanit viittaavat aiempaan kirjallisuuteen ja muuhun kulttuuriin osin varsin suoraan, niissä kaupunkitila rakentuu ensisijaisesti tietyn yhteisön tuottamana ja viralliselle kulttuurille vaihtoehtoisena merkitysverkostona. Merkityksen tuottamisen prosessi on siten lähtökohtaisesti sosiaalisesti latautunut, minkä vuoksi tilaa ei voida tarkastella yksinomaan intertekstuaalisena verkkona ilman siinä toimivaa ja merkityksiä muodostavaa yksilöä. Ymmärrämmekin tilan paitsi kulttuuristen tekstien välisinä vaikutussuhteina myös Henri Lefebvren (1991, 26-27, 30-33) ja hänen ajattelustaan kumpuavan kulttuurintutkimuksen tradition tapaan sosiaalisesti tuotettuna: tila ei ole ennalta annettu vaan syntyy yksilöllisen ja yhteisöllisen kokemuksen ja toiminnan tuloksena (de Certeau 1984, 97-98; ks. myös Ameel 2013, 51-56).

\section{Kaupunkitilan merkityksellistäminen romaanissa Vihreän teltan alla}

Vihreän teltan alla kertoo 1960-lukulaisen älymystön pyrkimyksistä säilyttää omaksi kokemansa vaihtoehtoinen kulttuuriperintö neuvostovallan puristuksissa. ${ }^{4}$ Romaanin keskiössä on kolme miestä (Ilja, Sanja ja Miha) ja kolme naista (Olja, Tamara ja Galja), joiden elämää kuvataan 50-luvun kouluvuosista aina 90-luvulle saakka. Ilja ja Olja päätyvät naimisiin keskenään, ja muiden elämät sivuavat toisiaan monin tavoin. Romaanissa muistamista käsitellään monimutkaisena kokonaisuutena: yksilöllisen ja kommunikatiivisen muistin tasolla pohditaan yksittäisten ihmisten ja sukujen historian siirtämistä sukupolvelta toiselle, kun taas kulttuurisen muistin tasolla romaanissa kasvaa laajempi "neuvostointelligentsijan tarina", joka näyttäytyy vallitsevalle ideologialle vaihtoehtoisena jatkumona.

Neuvostoälymystön tarina yhdistyy romaanissa Moskovaan kaupunkitilana. Innostava nuori kirjallisuudenopettaja Viktor Juljevitš esittelee venäläisen kirjallisuuden oppilailleen "monihaaraisena perheenä", eräänlaisena virallisen ateistisen ideologian alle vaimennettuna "Venäjän Raamattuna” (VTA, 95-96), jossa kirjailijoiden suvut linkittyvät toisiinsa. Hän tutustuttaa oppilaidensa parhaimmistoa eli "Venäläisen sanataiteen ystäviä” tähän perheeseen viemällä näitä kävelyretkille, joilla Moskovan talot ja kadut muuttuvat eläväksi kirjallisuushistoriaksi: "Kuin pillipiipari hän johdatti heidät köyhästä ja sairaasta ajasta sellaiseen avaruuteen, jossa ajattelu toimi ja jossa vapaus, musiikki sekä kaikki muutkin taiteet olivat elossa. Täällä, täällä se kaikki oli asustanut! Näiden ikkunoiden takana!” (VTA, 94.) $)^{5}$ Viktor Juljevitšin kylmän sodan aikaiseen Moskovaan rakentama vaihtoehtoinen kulttuurihistoriallinen jatkumo välittyy edelleen, kun hänen oppilaansa myöhemmin johdattavat samanmielisen lähipiirinsä kaupungin katujen kirjallisuushistoriaan:

Oljan ja Iljan rakkaustarina eteni pääsääntöisesti jalan, Iljan hyvin tuntemia Moskovan salattuja paikkoja kierrellen. Joskus hän pysähtyi kallellaan olevan notkokattoisen talon eteen ja sanoi: tämä on ajalta ennen tulipaloa, Vjazemski kävi täällä usein... tässä Mandelstam majaili veljensä luona... tästä apteekista 
Bulgakovin vaimo Jelena Sergejevna kävi hakemassa lääkkeitä miehelleen... (VTA 170.) $)^{6}$

Kävelyretket rakentavat konkreettiseen, kaikille näkyvään katukuvaan näkymättömän merkitysten verkon, jonka vain asiaan vihkiytyneet voivat hahmottaa ja joka näyttäytyy vaihtoehtoisena virallisen ideologian muistin paikoille (Nora 1989, 7; den Boer 2008, 20-21), neuvostohistoriaa symboloiville ja sen hegemoniaa ylläpitäville monumenteille, patsaille ja rakennuksille. Näin Ulitskajan toisinajattelijaälymystö rakentaa julkisesta tilasta oman, vallalla olevan ideologian vastaisen todellisuutensa - Moskova ei näyttäydy vain neuvostovallan pääkaupunkina vaan myös Venäjän klassisen kirjallisuuden kaupunkina.

Vaihtoehtoisen kaupunkitilan rakentaminen näyttäytyy ensisijaisesti vallitsevan neuvostoideologian kritiikkinä. Niinpä Viktor Juljevitš esimerkiksi kieltäytyy käyttämästä kaduista niiden neuvostoaikaisia nimiä ja pitäytyy sinnikkästi tsaarinaikaisissa. Neuvostohallinnon perspektiivistä sallitun reunamilla liikkuvat kävelyretket eivät kuitenkaan kyseenalaista pelkästään nykytilaa vaan kansalaisten vapauksia rajoittamaan pyrkivän valtion ylipäänsä - 1960-luvun toisinajattelijasukupolven edeltäjiksi nousevat erityisesti 1820-luvun vallankumoukselliset dekabristit ja Puškinin hahmo. ${ }^{7}$ Valtiokoneisto seuraa päähenkilöitä kuin Puškinia aikanaan, taiteilija Muratovin rakastajatar vertautuu esiäitiinsä, joka "vehtasi Puškinin kanssa" (VTA, 419) ${ }^{8}$, ja 1960-lukulaisten valinnat uskollisuuden ja petturuuden välillä rinnastuvat dekabristien vastaaviin valintoihin vuoden 1825 kapinan jälkimainingeissa. Romaanin päähenkilöiden elämä saa merkityksensä sen tilan kautta, jonka he jakavat menneisyyden suurmiesten kanssa: "Aljona ja Miha vilkaisivat toisiaan: osoitteiden sijaan tälllä asuttiin historian keskellä. Myös Pasternak oli parikymmentä vuotta sitten astellut tätä kujaa. Sataviisikymmentä vuotta sitten taas Puškin... Samassa paikassa kävelemme mekin, ikuisia lätäköitä kierrellen.” (VTA, 678.) ${ }^{9}$ Vaihtoehtoisen kulttuurihistorian läsnäolo ei romaanissa rajoitu vain Moskovaan, vaan Puškinin esitetään olevan vastaavalla tavalla läsnä esimerkiksi Krimillä, jonne päähenkilöt matkustavat. Ulitskajan romaanin aikakäsitys, jossa menneisyyden suuret tapahtumat toistuvat nykyajassa ja antavat arkisen profaanille merkityksen (vrt. Eliade 1993, 34-35; Clark 1981, 39-41), kun myyttisiä mittoja saavat venäläisen kirjallisuuden kultakauden (zolotoi vek) ja hopeakauden (serebrjanyi vek) hahmot elävät uudelleen teoksen henkilöissä, on tuttu myös neuvostokirjallisuudesta. Ulitskajan romaani käyttääkin osaksi samoja keinoja oman vaihtoehtoisen maailmankuvansa luomiseen kuin neuvostokirjallisuus käytti omansa rakentamiseen ja ylläpitämiseen.

Jos kaupunkitila ymmärretään lefebvreläisittäin sosiaalisesti tuotettuna vallankäytön välineenä, voidaan Ulitskajan henkilöiden pyrkimys rakentaa vaihtoehtoinen kulttuurinen merkitystodellisuus nähdä valtasuhteiden uudelleenmäärittelynä. Lefebvrelle kaupunki on jatkuva kamppailun tila. Ideaalitapauksessa se toimii erilaisia näkökantoja 
edustavien ryhmien yhteisenä projektina, jonka tuloksena syntyy uusia tapoja elää ja asua, mutta useimmiten se toteutuu vallanpitäjien määrittämänä epädemokraattisena, yksilönvapauden tukahduttavana haltuunottona (Lefebvre 1996, 158, 173-174). Ulitskajalla kaupunkitilan vaihtoehtoistaminen näyttäytyy lisäksi korostuneen yksilöllisenä toimintana. Siinä missä virallinen Moskova esitetään ylhäältäpäin toimivana ja kaikkialle ulottuvana tarkkailevan vallan verkostona, kirjallisuushistoriallinen Moskova syntyy alhaaltapäin, manipuloidun tilan jalkaisin tapahtuvana merkityksellistämisenä (vrt. de Certeau 1984, 96).

Mikrohistoriallinen vaihtoehtoisen todellisuuden luominen kontrolloituun tilaan tulee esille myös siinä, miten neuvostohistorian rakentamisessa keskeiset spektaakkelit kuten Stalinin hautajaiset esitetään Ulitskajalla yksittäisen ihmisen perspektiivistä, jonka avulla pyritään haastamaan kanonisoitu historia. Virallisista hautajaisista mainitaan lukijalle vain tapahtumapaikka, Liittojen talon Pylvässali, jossa ruumis oli näytteillä. Sen sijaan Moskovan katujen painajaismainen kaaos, jossa sadat ihmiset saivat surmansa, kuvataan yksityiskohtaisesti 12 -vuotiaan Iljan ruohonjuuritason näkökulmasta. ${ }^{10} \mathrm{Ilja}$ uskaltautuu kadulle saadakseen valokuvia arkistoonsa ja liikkuu viranomaisten hallinnasta karkaavassa kaoottisessa ihmisvirrassa omia, epävirallisia reittejään - takapihoja, kattoja ja viemäreitä pitkin - ja löytää tiensä kerrostalon porraskäytävään, josta hän voi kuvata tilannetta ylhäältä käsin. Pyrkimyksistään huolimatta hän ei kuitenkaan pääse katolle asti vaan joutuu tyytymään neljännen kerroksen ikkunasta avautuvaan näkymään, joten lopputuloksena ei ole kaikenkattava kokonaiskuva lintuperspektiivistä vaan rajoittunut, yksittäisen ihmisen näkökulma. Valokuvaaminen on esimerkki teoksessa toistuvasta motiivista, henkilöiden pyrkimyksestä luoda oman sukupolvensa kokonaisvaltainen tulkinta ympäröivästä todellisuudesta ja tämän pyrkimyksen osoittautumisesta mahdottomaksi, mitä korostaa myös se, että Iljan valokuvista ainoastaan yksi onnistuu.

\section{Romaanin Naisten aika kaksoistodellisuus}

Tšižovan romaani sijoittuu pääosin 50-luvun lopun Leningradiin, kaupungin keskustassa sijaitsevaan yhteisasuntoon, jonka kolme vanhaa naista - Ariadna, Glikeria ja Jevdokia - jakavat maalta tehtaaseen töihin muuttaneen, romaanin lopussa kuolevan yksinhuoltajaäiti Antoninan ja tämän mykän tyttären Susannan kanssa. Äitinsä kuoleman jälkeen Susanna alkaa puhua, ja hänestä tulee menestynyt kuvataiteilija. Tšižovan romaanin henkilökaarti ei edusta valveutunutta toisinajattelijaintelligentsijaa: mummoista ainoastaan Ariadna on saanut jonkin verran koulusivistystä, ja Antonina on naiivisti kommunismiin uskova maalaisnainen. Mummot ovat kuitenkin Ulitskajan romaanin sivistyneiden välittäjähenkilöiden tapaan voimakkaan tietoisia toisenlaisesta kulttuurista: he välittävät osin vaistonvaraisesti ortodoksista perinnettä uudelle naissukupolvelle. Susanna kasvatetaan kotona, koska naiset pelkäävät hänen joutuvan 
mykkyytensä vuoksi tarhasta hoitolaitokseen, ja niinpä hän saa varsin toisenlaisen kasvatuksen kuin keskiverto neuvostolapsi. Kyse on sekä kulttuurisen että kommunikatiivisen muistin välittämisestä, sillä mummojen arkisessa kasvatustyössä ortodoksinen kaanon sekoittuu satuihin, muistoihin ja heidän omiin elämäntarinoihinsa. Tätä perimää Susanna vuorostaan välittää aikuisena kuvataiteilijana eteenpäin.

Romaanissa mummojen uskonnollisuudesta ja Susannan mykästä taiteesta syntyvä tietoisuus lävistää jokapäiväisen neuvostoarjen. Mummot kastattavat Susannan tämän äidiltä salaa Sofiaksi, koska he ajattelevat nimen heijastavan ihmisen kohtaloa: Susanna on sopiva nimi ihmisten edessä mutta Jumalan edessä hän on Sofia. Susannan ”todellinen” nimi yhdistyy paitsi viisauteen myös naiseuteen, sillä venäläisessä kulttuurissa Sofia symboloi ikuista naisellisuutta, äiti-Venäjää (ks. Rjabov 1999, 25-35). ${ }^{11}$ Susanna-Sofia luo mielikuvituksessaan ja taiteessaan vaihtoehtoisen maailman, joka kiteytyy hänen askartelemaansa paperitaloon - talo ei ole yhteisasunto vaan perheen ikioma. Tämän koko romaanille ominaisen kaksoistodellisuuden taustalla voi nähdä usein venäläiselle kulttuurille ominaisena pidetyn jaon arkiseen, matalaan, jokapäiväiseen ja väliaikaiseen (byt) ja henkiseen, korkeaan, poeettiseen ja ikuiseen (bytije) todellisuuteen, jonka on nähty juontuvan ortodoksisuudelle tyypillisestä jaosta maalliseen synnilliseen olemassaoloon ja sen takana olevaan siunattuun transsendenssiin (ks. Lotman \& Uspenski 1985, 32). ${ }^{12}$ Esillä oleva maailma näyttäytyy romaanissa siten valheellisena ja väliaikaisena, kun taas sen takana hahmottuu ikuinen totuuden ja viisauden maailma, jota mummot ja Susannan todellinen minuus - Sofia - edustavat.

Väliaikaisen ja ikuisen todellisuuden yhtäaikainen läsnäolo koskee korostuneesti Leningradin kaupunkitilaa, joka hahmottuu Ulitskajan Moskovan tapaan yhtäältä kaikille näkyvissä olevana ja toisaalta vain harvoille ja valituille avautuvana vaihtoehtoisena todellisuutena. Mummojen tulkinnassa konkreettinen arkinen Leningrad on pinta - sen alla on syvempi, neuvostokulttuurin ulottumattomissa oleva todellisuus, johon mummot johdattavat Susannaa päivittäisillä kävelyretkillä samaan tapaan kuin Viktor Juljevitš tutustuttaa oppilaitaan Venäjän kirjallisuushistoriaan Ulitskajan romaanissa: "'Älä rämmi kurassa', Glikeria sanoo, 'tai astut seuraavassa hetkessä ties mihin. Lumen alla on piilossa vaikka mitä: koirankakkaa ja kaikkea mädäntynyttä. Ne luulevat että lika on imeytynyt maaperään saakka. Mutta maa on jäinen ja kiinteä, ei se ota vastaan niiden sontaa.”' (NA, 145; suom. TK ja JS.) ${ }^{13}$ Leningradin maaperän voi nähdä yhdistyvän Susanna-Sofian nimen symboloimaan ikuiseen äiti-Venäjään, jota neuvostokoirankakka ei kykene likaamaan. Samoin Pietari-Leningradin mytologiaan yhdistyvät maamerkit näyttäytyvät ikuisina toisin kuin kaupungin täyttävät ihmiset:

"Sinun täytyy painaa kaikki mieleesi nyt kun vielä on aikaa", Glikeria sanoo katsellen ympärilleen. "Meidän talo on tuolla. Ja tuossa on tuomiokirkko.

Sinä muistat varmasti, olemmehan käyneet täällä niin usein kävelyllä. Jos sattuisit unohtamaan, niin kirkontorni on korkea. Sen voi nähdä kaikkialta. 
Anna sen opastaa sinua. Mutta jos tulet kanaalin suunnalta niin asia on toinen: sinun täytyy ylittää silta, mennä leijonien ohitse. Leijonat ovat kivisiä - ne eivät katoa. Vaan ihmisiltä", hän heristää sormeaan, "älä kysy neuvoa. Voivat sanoa mitä vain, neuvoa väärin tai napata mukaansa. Minä kirjailen sinun nimikirjaimesi”, hän lohduttaa. ”Niin että löydät itse, kävelet muistin mukaan." (NA, 145.) ${ }^{14}$

Kaksoistodellisuuden problematiikka yhdistyy romaanissa myös pietarilaistekstin traditioon, jonka yhtenä keskeisimpänä nykyedustajana Tšižovaa usein pidetään. Pietarilaisteksti on läsnä paitsi ajatuksessa kahdesta eri todellisuudesta myös alluusioina Dostojevskin Rikokseen ja rangaistukseen (1866), jonka tematiikkaa Naisten aika heijastelee eri tavoin. Tšižova esimerkiksi rakentaa mummojen ja Susannan tulevan isäpuolen Nikolain suhteesta viitteen Raskolnikoviin: Ariadna lupaa jättää kalliit korvakorunsa perinnöksi Nikolaille, jos tämä nai kuolevan Antoninan. Samoin romaanin keskeisessä sisäkertomuksessa, Nikolain Antoninalle kertomassa tarinassa nuoruudestaan, Nikolain kaveri kotikylästä päätyy asuntoa etsiessään palaamaan yhä uudelleen huoneistoon, jonka omistavan mummon hän epäilee tulleen murhatuksi ja piilotetuksi lattialautojen alle.

\section{Kulttuurinen muisti ja epävirallisen yhteisöllisyyden tilat}

Naisten ajan ensisijainen tapahtumaympäristö on neuvostoajan yhteisasunto, kommunalka, jossa yksityisyydelle ei juuri ole sijaa. Henkilöt määrittyvät hierarkkisesti sen suhteen, minkälainen asunto heillä on, ja oman tilan tavoittelu määrittää heidän toimintaansa. Tavoiteltavimmalla tasolla on Glikeria-mummon omassa huoneistossa asuva nuoruudenrakastettu, seuraavaksi tulevat yhteisasunnon asukkaat, mummot ja Antonina tyttärineen, ja alimpana on Nikolai, joka on elänyt viisitoista vuotta tehtaan yhteisasuntolassa. Nikolain asunnontarve saa keskeisen merkityksen romaanin juonessa. Kun selviää, että Antonina on kuolemansairas ja ettei mummoilla ole mahdollisuuksia saada Susannan virallista huoltajuutta, Ariadna oivaltaa Nikolain asunnontarpeessa mahdollisuuden pelastaa tyttö orpokodilta. Niinpä Nikolai nai Antoninan pääasiassa siksi, että perheellisyys takaa mahdollisuuden omaan asuntoon, mikä puolestaan mahdollistaa Susannan asumisen isoäitien luona.

Yksityinen ja kollektiivinen tila asettuvat romaanissa toistuvasti vastakkain. Asunto ei ole pelkkä asunto vaan määrittää yksilön autonomisuutta. Antoninan elämä näyttäytyy yksityisen kamppailuna kollektiivista vastaan: "Yhdeksän ja puoli neliötä omaa tilaa. [--] Niille se ei tietenkään merkitse mitään: ”'Et sinä ole ensimmäinen etkä viimeinen. Ja muista, että lapsi on meidän, tehtaan lapsi. Yhteinen siis. [--] Etkä sinäkään ole onneksi yksin vaan osa kollektiivia.” (NA, 9.) ${ }^{15}$ Virallinen yhteiskunta eri laitoksineen, kuten sosiaalitoimisto, jossa Ariadna asioi, esitetään yksilöä nöyryyttävänä ja epäinhimillisenä. Susannan mykkyys puolestaan nousee romaanissa keskeiseksi yksityisen ja 
kollektiivisen suhdetta reflektoivaksi metaforaksi. Sen vastakohta on virallisen valtion kaikkialle penetroiva ääni ja aivan erityisesti Antoninan yhteisasuntoon hankkiman, jatkuvasti auki olevan television yksityiseen tilaan tunkeutuva propaganda. Susannan mykkä maailma näyttäytyy television kuvaaman illusorisen sosialismin vastapoolina, autenttisena yksityisyyden tilana; kuten Marja Sorvari $(2014,20)$ esittää, Susannan mykkyyden voi nähdä kieltäytymisenä astumisesta kielen, lain ja järjestyksen maailmaan ja siten pysyttäytymisenä virallisen yhteiskunnan ulottumattomissa. Mykkyyteen yhdistyy vastaavankaltaisia ajatuksia myös teoksen arvomaailmaan kiinteästi liittyvässä ortodoksisuudessa.

Tšižovan romaanissa yksityisyys ja kollektiivisuus näyttäytyvät vastakohtaisina kuitenkin vain suhteessa viralliseen yhteiskuntaan ja sen instituutioihin. Juuri kollektiivisen ideologian huipentuma, yhteisasunto, suojaa Susannaa ja tekee mahdolliseksi kasvattaa hänet neuvostoideologian saavuttamattomissa. Yhteisasunnon asukkaista tulee perhe ja asunnosta koti: läheisensä menettäneet mummot saavat lapsen ja lapsenlapsen, ja Antonina puolestaan saa kolme äitiä kuolleen äitinsä tilalle. Jokapäiväisen elämän raskaudesta huolimatta naisten epävirallinen kommuuni näyttäytyy autenttisena yhteisöllisyytenä keinotekoisen sosialistisen kollektiivisuuden keskellä. Yhteisasunto ei siten näyttäydy kodin vastakohtana, toisin kuin Juri Lotman $(1990,191)$ esittää, vaan pikemminkin kollektisoivan yhteiskunnan marginalisoimien yksilöiden mahdollisuutena perheeseen ja kotiin. Tämä koskee erityisesti yhteisasunnon keittiötä, joka märittyy Tšižovalla pääosin myönteisenä yhteisöllisyyden tilana. Keittiössä käydään kaikki tärkeät keskustelut; se on niin merkityksellinen paikka, että Susanna ajattelee keittiön kuolevan yhdessä mummojen kanssa, jotta nämä voivat jatkaa elämäänsä tuonpuoleisessa. ${ }^{16}$

Naisten välinen autenttinen yhteisöllisyys, jonka sosialistinen asuntopolitiikka paradoksaalisesti mahdollistaa, liittyy romaanissa ortodoksisessa ajatteluperinteessä keskeiseen yhteisöllisyyden ideaan, sobornostiin, joka erityisesti 1800-luvun slavofiiliajattelijoista lähtien näyttäytyy vastakkaisena läntiselle individualistiselle yksilökäsitykselle. Sobornostin ydin on ajatuksessa eri yksilöiden välisestä spontaanista toiminnasta yhteisen tavoitteen hyväksi. Tšižovan romaanissa sobornost näkyy mummojen yhteistoiminnassa Susannan pelastamiseksi. Toisaalta myös aikuisen kuvataiteilija-Susannan valinnat noudattelevat nekin sobornostiin sisältyvää individualismikritiikkiä: kun poikaystävä loikkaa länteen voidakseen toteuttaa itseään taiteilijana, Susanna kieltäytyy emigroitumasta, koska ajattelee voivansa jatkaa mummojen perintöä ainoastaan Venäjällä.

Ulitskajan romaanissa yksityinen tila ei ole turvapaikka samassa mielessä kuin Naisten ajassa. Toisin kuin marginaalissa elävien mummojen, neuvostovallan kannalta uhkaa edustavan älymystön kodit ovat aina vaarassa: asunnoissa on kuuntelulaitteita, ja kotietsintä voidaan tehdä koska hyvänsä. Suurinta vapautta romaanihenkilöt tuntevat Moskovan ulkopuolella, periferiassa kaukana vallan keskuksesta (vrt. Voronina 2014, 
110). Oljalle vapauden paikaksi muodostuu pohjoisvenäläinen metsäluonto, hänen isälleen perheen kesäasunto. Taiteilija Muratov tuntee uudenlaista vapautta paettuaan viranomaisia maaseudun syrjäkylään. Päähenkilöiden koteja ei uhkaa vain ulkopuolelta tilaan tunkeutuva valtakoneisto, vaan virallinen neuvostoideologia on jatkuvasti läsnä myös kotona. Paras esimerkki tästä on Oljan lapsuudenkoti, jota hallitsee äiti, Neuvostoliiton kirjailijaliiton korkeassa asemassa oleva virkailija. Oljan äiti edustaa neuvostokirjallisuuden virallista kaanonia, jonka varjossa Olja luo oman sukupolvensa toisinajattelijakirjallisuuden kaanonia kirjoittamalla puhtaaksi kiellettyä kirjallisuutta milloin äitinsä asunnossa, milloin kenraali-isänsä kesämökillä.

Silti Ulitskajankin teoksesta löytyy ajatus kodista spontaanisti syntyvän yhteisöllisyyden mahdollistavana turvasatamana. Romaanin keskeisin yksityinen tila, Sanjan koti, hahmottuu Tšižovan yhteisasunnon tapaan yhteisöllisen harmonian tilana. Sanja kuuluu vanhaan venäläiseen kulttuurisukuun, ja perhe asuttaa "Apraksin-Trubetskoi-suvun entisen aateliskartanon pienen salin osaa" (VTA, 26) ${ }^{17}$, jossa myös työläistaustaiset Ilja ja Miha pääsevät tutustumaan vallankumousta edeltäneeseen yläluokan kulttuuriin. Tällä menneen maailman henki on aina läsnä, jollei muuten niin ainakin Sanjan isoäidin ruokakaapista lehahtavina tuoksuina: "Anna Aleksandrovna kaiveli kaappia. Tänään sieltä ei löytynyt mitään erityistä, kuivia rinkeleitä ja korppuja vain. Mutta aina kun kaapin yläovi avattiin, sieltä lehahti vaniljan ja vielä jonkin vallankumousta edeltävän tuoksua, josta Miha piti kovasti." (VTA, 113. ${ }^{18}$ Isoäiti Anna Aleksandrovna on Sanjan kodin sydän ja Ulitskajan romaanin toinen keskeinen välittäjähahmo kirjallisuudenopettaja Viktor Juljevitšin lisäksi. Kulturelli isoäiti tutustuttaa pojat klassiseen venäläiseen kirjallisuuteen ja musiikkiin kävelyretkin, museovierailuin ja konserttikäynnein. Hän on korostuneen myönteinen hahmo, sivistyneen venäläisnaisen ruumiillistuma, joka jatkaa venäläisessä nykykirjallisuudessa toistuvaa Anna Ahmatovaan viittaavaa linjaa. ${ }^{19}$ Sanjan koti on Iljalle ja Mihalle samankaltainen vaihtoehtoisen kulttuurin välittymisen tila kuin Ahmatovan Kellomäki Joseph Brodskylle ja muille Ahmatovan kotona kokoontuneille 1960-lukulaisille toisinajattelijarunoilijoille. Isoäidin erityissuosikki, myöhemmin vankileirille joutuva punahiuksinen juutalaispoika Miha saakin Brodskyyn viittaavia piirteitä, joskin hahmolle löytyy muitakin esikuvia: Mihan elämäntarina viittaa selvästi myös runoilija ja ihmisoikeusaktivisti Ilja Gabaihin (Latynina $2011,175-176) .^{20}$

\section{Lopuksi}

Kulttuurisen muistin tarkastelu suhteessa tilaan Ljudmila Ulitskajan ja Jelena Tšižovan keskeisissä romaaneissa osoittaa, että kylmän sodan aikaisen historian uudelleenkirjoittaminen on venäläisessä kirjallisuudessa edelleen tärkeässä osassa. Vihreän teltan alla ja Naisten aika kulkevat perestroikan ajan ja 90-luvun vaihteen kirjallisuuden jalanjäljissä 
siinä mielessä, että niiden näkökulma neuvostoaikaan on korostuneen mikrohistoriallinen. Ulitskajalla ruohonjuuritason näkökulma laajoihin yhteiskunnallis-historiallisiin tapahtumakaariin syntyy Sodan ja rauhan kaltaisessa, kymmenien romaanihenkilöiden kautta suodattuvassa kokemuksessa, jollainen on venäläisessä kirjallisuudessa perinteisesti tyypillisempi miesten kirjoittamalle kirjallisuudelle. Tšižovalla taas kylmän sodan aikaista yhteiskuntaa tarkastellaan pääosin yhden havainnoivan tietoisuuden, Susanna-Sofian, kautta. Tšižovan romaanin voi nähdä sodanjälkeisten vuosikymmenien Neuvostoliiton historiaa heijastelevana naistaiteilijaromaanina, jossa päähenkilön mykkyys lopulta muuttuu ääneksi ja ilmaisuksi. Toisin kuin läntisessä perinteessä, Tšižovan taiteilijaromaanissa ei korostu päähenkilön yksilöllinen kehitys vaan taiteilijan elämäntarinan yhteisöllisyys. Samalla romaanissa painottuu kertomisen etiikka, kun Susanna kirjoittamalla tarinansa välittää oman ja isoäitien elämänkokemuksen eteenpäin.

Kulttuurisen muistin välittyminen yhdistyy kummassakin romaanissa korostuneesti tilallisuuteen. Tšižovalla määritellään uudelleen yksityisen ja kollektiivisen tilan välistä suhdetta. Kollektiivisuus saa Naisten ajassa sekä kielteisiä, virallisen yhteiskunnan ideologiaan yhdistyviä piirteitä että myönteisiä, eri sukupolvia edustavien naisten väliseen epäviralliseen yhteisöllisyyteen liittyviä ulottuvuuksia. Tämä problematiikka tiivistyy neuvostoaikaiseen yhteisasuntoon tilana. Spontaani kollektiivisuus liittyy kiinteästi ortodoksisessa perinteessä keskeiseen sobornostin traditioon, jossa yhteisöllisyys määrittelee yksilön valintoja.

Romaanissa Vihreän teltan alla puolestaan nousee merkitykselliseksi kontrolloidun tilan haltuunotto, Moskovan muuntuminen vallan ja virallisen kulttuurin keskuksesta myös vaihtoehtoisen kulttuurisen jatkumon mahdollistavaksi tilaksi. "Vihreä teltta" yhdistyy romaanissa konkreettisesti Oljan juuri ennen kuolemaansa näkemään enneuneen, jossa hän jonottaa häätelttaan yhdessä länteen emigroituneen ja nyt jo kuolleen miehensä Iljan kanssa. Unen hääteltta viittaa Oljan ja Iljan toisten suhteiden sivussa elävään rakkaustarinaan, joka romaanissa rinnastuu vaihtoehtoiseen kulttuuriin. Hopean ja kullan sävyjä saava vihreys on toistuva motiivi romaanin kokonaisuudessa ja symboloi järjestelmän sisällä mahdollistuvaa toista tilaa, klassisen musiikin ja aivan erityisesti hopea- ja kultakauden kirjallisuuden Ulitskajan toisinajattelijoille tarjoamaa suojaa. ${ }^{21}$ Tämän Ulitskajan romaanissa korostuvan kulttuurisen jatkumon, jossa kirjallisuushistoria elää itseään uudelleen yhä uusissa sukupolvissa kulloisestakin yhteiskunnallisesta järjestelmästä riippumatta ja siten toisintaa myyttistä kulta-aikaa, voi nähdä suhteessa Naisten ajan ajallisuuteen. Tšižovan kaikille läsnäolevan jokapäiväisen Leningradin takana pilkottaa bytijen korkeampi ja pysyvämpi todellisuus, jota naissukupolvet kannattelevat aikakaudesta toiseen.

Kummassakin romaanissa vaihtoehtoinen kaupunkitila rakentuu yksilöllisessä ja yhteisöllisessä toiminnassa. Naisten aika käyttää hyväkseen pietarilaistekstin traditiota ja viittaa suoraan aiempaan kaunokirjallisuuteen, erityisesti dostojevskilaiseen kaksois- 
todellisuuteen. Romaanin Vihreän teltan alla intertekstuaalinen Moskova sen sijaan syntyy toisella tavalla. Ulitskajan viitteet eivät kohdistu ensisijaisesti aiempaan kaunokirjallisuuteen vaan kirjalliseen kulttuuriin: kirjailijoihin henkilöinä, näiden lähipiiriin ja elämäkertoihin. Romaanin voi nähdä uudenlaisena "moskovalaistekstinä”, jossa mittava kirjallisuushistoriallisten viittausten verkosto rakentuu konkreettisesta kaupunkitilasta kumpuavina, kirjailijoiden elämänkohtaloihin yhdistyvinä risteävinä tarinoina. Romaanin tulkitsemisessa näiden tarinoiden ja niiden henkilöiden tunnistaminen ei ole välttämätöntä, kun taas Naisten ajan ymmärtämisessä pietarilaistekstin tradition tuntemuksen merkitys on suuri.

\section{Viitteet}

${ }^{1}$ Uudesta realismista ks. esim. Rotkirch 2012 ja Klapuri \& Lappela 2015.

${ }^{2}$ Tšižovan romaania ei ole suomennettu mutta se on kännnetty esimerkiksi englanniksi (The Time of Women, 2012) ja saksaksi (Die Stille Macht der Frauen, 2012).

${ }^{3}$ Sen sijaan "tilallinen käänne" näkyy hyvin siinä, miten fokus on erityisesti läntisessä venäläisen kulttuurin tutkimuksessa siirtynyt pääkaupungeista rajoille ja keskuksesta periferiaan (ks. esim. Turoma \& Waldstein 2013). Pietarilaistekstillä tarkoitetaan Pietarin kaupunkiin yhdistyvää kaunokirjallista mytologiaa, joka syntyy Puškinilla ja jatkuu Gogolin ja Dostojevskin teoksissa. Tässä mytologiassa Pietari Suuren perustama eurooppalainen kaupunki tarkoittaa länteen yhdistyvää ja Venäjälle vierasta keinotekoisuutta ja rationaalisuutta, jonka takana väijyvät kuitenkin erilaiset äärimmäisyydet, mielipuolisuus ja ennakoimattomuus. 1900-luvulla pietarilaisteksti näkyy erityisesti runoudessa, Anna Ahmatovalla ja myöhemmin Joseph Brodskylla ja Jelena Švartsilla, mutta myös Andrei Bitovin romaaneissa ja Tatjana Tolstajan novellistiikassa. Pietarilaistekstistä tarkemmin ks. esim. Antsiferov 1990; Lotman (red.) 1984; Pesonen 1983.

${ }^{4}$ 60-lukulaisilla tarkoitetaan noin vuosina 1925-1945 syntynyttä intelligentsijasukupolvea, jonka elämää ovat määrittäneet stalinismin aika, toinen maailmansota ja suojasään kausi. Ulitskaja (ks. esim. 2011) on todennut kuuluvansa pitkälti itsekin samaan sukupolveen.

5 «По средам Виктор Юльевич таскал любителей русской словесности, «люрсов», как они себя называли, по Москве и выводил их, дуя в свою флейточку, из бедного и больного времени в пространство, где работала мысль, где жила свобода, и музыка, и всякие искусства. Вот, здесь все это обитало! За этими окнами!» (Z ̌̌, 74.)

${ }^{6}$ «Роман Ольги и Ильи протекал главным образом на ногах, в прогулках по сокровенномосковским местам, которые он хорошо знал. Иногда он останавливался возле кривого домика с покосившимся крыльцом и говорил: это дом допожарный, сюда Вяземский захаживал... Здесь, у брата, Мандельштам останавливался... а в эту аптеку бегала жена Булгакова Елена Сергеевна за лекарствами для мужа...» (Ž̌, 134.$)$

${ }^{7}$ Ulitskaja (2011) on haastattelussa rinnastanut romaanissa kuvatun epävapaan valtion myös Venäjän yhteiskunnan nykytilaan.

8 «- У Насти кровь такая - прабабка или прапра... с Пушкиным путалась» (ŽS, 325).

${ }^{9}$ «Алена переглядывалась с Михой: не в подворотне живем, в истории... И Пастернак по этому переулку ходил каких-то двадцать лет тому назад. А сто пятьдесят лет тому - Пушкин... И мы тут проходим, огибая вечные лужи.» (ZŠ, 525.) 
${ }^{10}$ Stalinin hautajaisspektaakkelin toisinkirjoittaminen on Ulitskajan tuotannossa toistuva motiivi. Esimerkiksi romaanissa Kazus Kukotskogo (2001, "Kukotskin tapaus") vaiettua tragediaa käsitellään ihmisjoukossa puikkelehtivien kahden nuoren tytön näkökulmasta. ${ }^{11}$ Tämä yhteys näkyy hyvin 1900-luvun vaihteen symbolismissa, jossa Sofian hahmo saa jumalalliseen naiseuteen ja äiti-Venäjään liittyviä ulottuvuuksia. Tšižovan romaanissa Sofian nimen symboliikka yhdistyy 1900-luvun vaihteen uskonnolliseen filosofiaan ja erityisesti Pavel Florenskin käsitykseen nimen merkityksestä kantajansa identiteetille (ks. Kahla 2012, 285).

${ }^{12}$ Arjen taustalla vaikuttava toinen todellisuus on esillä myös Vihreän teltan alla-romaanissa, jossa tähän toiseen todellisuuteen voi saada yhteyden taiteen kautta.

${ }^{13}$ «- Ты, - учит, - по грязи не шлепай. Шаг сделаешь - вмиг вступишь. Под снегом-то все спряталось: и какашки собачьи, и гнилье. Вот они и думают, будто грязь в землю ушла. А земля тугая, мерзлая - ихней грязи не принимает.» (NA, 145.)

${ }^{14}$ «- Тебе, - вокруг себя оглядывается, - всего запомнить надо, пока время у нас есть. Дом наш - вон где. А тут собор. Сколько лет ходили, должна уже помнить. Если что, колокольня высокая. Ее отовсюду видно. По ней и равняйся. А из-за канала выйдешь - там другое: через мостик надо идти, мимо львов. Львы-то каменные - что им сделается? А людей, - пальцем грозит, - не спрашивай. Мало ли... Запутают, заведут. Я, - утешает, - буковки твои вышью. Так что на себя надейся - по памяти ступай.» (NA, 145.)

${ }^{15}$ «Девять с половиной метров - сама себе барыня. [--] Им-то чего: «Не ты первая, не ты последняя. И помни: ребеночек наш, заводской. Значит, общий. [--] Да и ты, небось, не одна - в коллективе.»» (NA, 9.)

${ }^{16}$ Yhteisasunnon keittiö on neuvostoaikaa kuvaavassa kirjallisuudessa erityisen merkityksellinen tila. Öinen keittiö näyttäytyy oman ajan tilana esimerkiksi Petruševskajan nykynaiskirjallisuuden traditiossa keskeisessä pienoisromaanissa Vremja - notš (1992, ”Aika on yö”), mutta siinä missä Petruševskajalla öinen keittiö korostaa minäkertoja-isoäidin yksinäisyyttä, Tšižovalla painottuu mummojen keittiön yhteisöllisyys.

17 «Сзади топорщились фрагменты быта, ничем не напоминавшие отрезок малой залы бывшей усадьбы Апраксиных-Трубецких, в котором обитало семейство Сани» (Ž̌, 22).

18 «Анна Александровна зашуршала в буфете. Сегодня там не было ничего особенного сушки да сухари. Но запах ванили и еще чего-то, дореволюционного, всегда оттуда шел, когда верхнюю створку распахивали, и Миха его очень любил.» (Ž́, 89.)

${ }^{19}$ Esimerkiksi Tatjana Tolstajan novellin ”Joki nimeltä Ockerville” Ahmatova-hahmo, unohtunut laulajatar Vera Vasiljevna, näyttäytyy kulttuurisen muistin kantajana kuten Ulitskajan Anna Aleksandrovnakin. Tolstajan postmodernissa kerronnassa Ahmatovan kulttihahmo kuitenkin karnevalisoidaan, kun taas Ulitskajan Ahmatova-hahmosta kaikki parodisuus puuttuu.

${ }^{20}$ Erityisesti Ulitskajan mutta myös Tšižovan tuotannossa toistuva näkemys uusintaa venäläisessä kirjallisuudessa 1800-luvulta tuttua käsitystä babuškasta ideaalina (ks. Savkina 2011). Toisaalla venäläisessä nykykirjallisuudessa isoäitikultti on joutunut raisun kritiikin kohteeksi: paitsi Petruševskajalla, isoäiti pudotetaan jalustaltaan esimerkiksi Pavel Sanajevin pikkupojan perspektiivistä kirjoitetussa romaanissa Haudatkaa minut jalkalistan taakse (Pohoronite menja za plintusom, 1996), jossa mielipuolisen mummon hirviömäisyys on tuhota koko perheen elämän.

${ }^{21}$ Ulitskaja itse selittää unen vihreän teltan symboloivan sovintoa, lopullista anteeksiantoa, yhtäältä menneisyyden ja nykyisyyden välillä ja toisaalta hänen oman sukupolvensa edustajien välillä (Vovk 2011). 


\section{Lähteet}

\section{Primäärilähteet}

Tšižova, Jelena 2010 (2009). Vremja ženštšin [= NA]. Moskva: Ast-Astrel.

Ulitskaja, Ljudmila 2011 (2010). Zeljonyi šatjor [= ZŠ]. Moskva: Eksmo.

Ulitskaja, Ljudmila 2014. Vihreän teltan alla [= VTA]. (Zeljonyi šatjor, 2010.) Suom. Arja Pikkupeura. Helsinki: Siltala.

\section{Sekundäärilähteet}

Ameel, Lieven 2013. Moved by the City: Experiences of Helsinki in Finnish Prose Fiction 1889-1941. PhD Thesis. Helsinki: Unigrafia.

Antsiferov, N. P. 1990 (1922). Dǔsa Peterburga. Leningrad: Lira.

Assmann, Jan 1995. Collective Memory and Cultural Identity. New German Critique 65, 125-133.

Assmann, Jan 2008. Communicative and Cultural Memory. Astrid Erll \& Ansgar Nünning (eds), A Companion to Cultural Memory Studies. Berlin: De Gruyter, 109-118.

den Boer, Pim 2008. Loci memoriae - Lieux de mémoire. Astrid Erll \& Ansgar Nünning (eds), A Companion to Cultural Memory Studies. Berlin: De Gruyter, 19-26.

de Certeau, Michel 1984. The Practice of Everyday Life. (Linvention du quotidien. Vol. 1, Arts de faire, 1980.) Transl. Steven Rendall. Berkeley: University of California Press.

Clark, Katerina 1981. The Soviet Novel: History as Ritual. Chicago: Chicago UP.

Eliade, Mircea 1993. Ikuisen paluun myytti. Kosmos ja historia. (Le mythe de l'éternel retour: Archetypes et répétition, 1949.) Suom. Teuvo Laitila. Helsinki: Loki-kirjat.

Kahla, Elina 2012. Jelena Tšižova - Mnemosynen palveluksessa. Tomi Huttunen \& Tintti Klapuri (toim.), Kenen aika? Esseitä venäläisestä nykykirjallisuudesta. Helsinki: Avain-BTJ, 277-288.

Klapuri, Tintti \& Anni Lappela 2015. 2000-luvun venäläinen uusi realismi. Avain $1 / 2015,88-93$.

Kunik, Abram 2013. Deti Ulitskoi "Zeljonyi šatjor". Roman o šestidesjatnikah. Novyi bereg 40. http://magazines.russ.ru/bereg/2013/40/18ku.html (3.4.2015).

Latynina, Alla 2011. "Vseh sovetskaja vlast ubila...” "Zeljonyi šatjor" Ljudmily Ulitskoi. Novyi mir 6, 169-177.

Lefebvre, Henri 1991. The Production of Space. (Production de l'espace, 1974.) Transl. Donald Nicholson-Smith. Malden: Blackwell.

Lefebvre, Henri 1996. Writings on Cities. (Le Droit à la Ville, 1968 \& Espace et politique, 1973). Transl. Eleonore Kofman \& Elizabet Lebas. Oxford: Blackwell.

Lotman, Ju. M. (red.) 1984. Semiotika goroda i gorodskoi kultury. Peterburg. Trudy po znakovym sistemam XVIII. Tartu: Tartuski gos. universitet. 
Lotman, Iurii 1990. Universe of the Mind: A Semiotic Theory of Culture. Transl. Ann Shukman. New York: I. B. Tauris.

Lotman, Iurii \& Boris Uspensky 1985. Binary Models in the Dynamics of Russian Culture. Alexander Nakhimovsky \& Alice Stone-Nakhimovsky (eds), Semiotics of Russian Cultural History. Ithaca: Cornell UP, 30-66.

Nora, Pierre 1989. Between Memory and History: Les Lieux de Mémoire. Representations 26, 7-24.

Pesonen, Pekka 1983. Katoava kaupunki. Myytti Pietarin kaupungista venäläisessä kirjallisuudessa. Parnasso 4, 231-241.

Rjabov, O.V. 1999. Russkaja filosofija ženstvennosti (XI-XX veka). Ivanovo: Junona.

Rotkirch, Kristina 2012. Roman Sentšin ja uusi realismi. Tomi Huttunen \& Tintti Klapuri (toim.), Kenen aika? Esseitä venäläisestä nykykirjallisuudesta. Helsinki: Avain-BTJ, 205-214.

Savkina, Irina 2011. U nas nikogda uže ne budet etih babušek? Voprosy literatury 2. http://magazines.russ.ru/voplit/2011/2/sa3.html (16.3.2015).

Sorvari, Marja 2014. Liminaalisuus, raja, communitas. Idäntutkimus 3, 15-25.

Turoma, Sanna \& Maxim Waldstein 2013. Empire and Space: Russia and the Soviet Union in the Focus. Sanna Turoma \& Maxim Waldstein (eds), Empire De/Centered: New Spatial Histories of Russia and the Soviet Union. Farnham: Ashgate, 1-28.

Ulitskaja, Ljudmila 2011. Novaja kniga Ljudmily Ulitskoi “Zeljonyi šatjor”. Ekho Moskvy 13.2.2011. http://echo.msk.ru/programs/kazino/748934-echo/ (3.4.2015).

Voronina, T. N. 2014. Vologodski krai v romane L. Ulitskoi "Zeljonyi šatjor". Vestnik Tomskogo gosudarstvennogo universiteta 9(150), 109-112.

Vovk, Svetlana 2011. "Zeljonyi šatjor" možet stat poslednim romanom Ulitskoi. Ria Novosti 9.2.2011. http://ria.ru/culture/20110209/332134299.html (29.5.2015). 